UDC 336.662

JEL Classification: J32, 016, M11

DOI: 10.15587/2312-8372.2019.170342

Hlasov P.

\title{
ANALYSIS OF PROBLEMS OF ACCOUNTING RELIABILITY PROVISION IN CLUSTERS
}

Об’єктом дослідження є теоретичні та практичні аспекти особливості формування управлінської звітності та проблемні питання запобігання спотворенню бухгалтерського обліку в кластерах. Питання оцінки якості облікової інформацї̈ зокрема, сутність і місце облікової інформачї в управлінні кластерами, бухгалтерський облік в інформаційній системі управління підприємств-учасників кластеру, інструментарій бухгалтерського обліку та звітності є недостатньо розробленими. Досліджується порядок формування облікової інформачї та підготовка управлінської бухгалтерської звітності в кластерах, а також визначаються особливості якості облікової інформації та ефективності системи бухгалтерського обліку. В процесі дослідження використовувалися методи узагальнення, систематизацї, системного аналізу. За допомогою цих методів запропоновано уточнення понять «внутрішньокорпоративна управлінська звітність», «необгрунтована класифікація витрат», «облікова інформація». Також згруповані основні проблеми, що гальмують необхідність впровадження та автоматизації системи повноцінного управлінського обліку, який би відповідав усім викликам та потребам сучасного бізнесу та запропоновані шляхи їх вирішення. Особлива увага в дослідженні приділяється формуванню інформачійного забезпечення для вирішення конкретних управлінських проблем. Незважаючи на певні успіхи в розвитку (зокрема, принципових засад стандартизаціі) обліку $і$ звітності, існують серйозні проблеми щодо адекватності методологічних основ обліку сучасному стану ринкового середовища і потребам користувачів. Системи бухгалтерського обліку, шо склалися, не забезпечують повною мірою належну якість і надійність інформації, яку вони формують, що істотно обмежує можливості корисного використання цієї інформації. У роботі достовірна бухгалтерська звітність проаналізована як важливий інструмент прийняття обгрунтованих та важливих управлінських рішень в кластерах. Результати проведеного дослідження стануть у нагоді при проведенні аудиторської перевірки, в тому числі при плануванні аудиту, тому що бухгалтеру і керівнику підприємства необхідно враховувати можливу наявність спотворень бухгалтерської звітності. I, виходячи з цього, оцінити ризик спотворень бухгалтерської звітності та прийняти міри по запобіганню таких порушень в майбутньому.

Ключові слова: управлінська звітність, облік витрат, фальсифікація фінансових показників, облікова інформація, ефективність управлінських рішень.

\section{Introduction}

The economic changes in Ukraine that have occurred in recent years have significantly influenced the introduction of the cluster model of the economy. In conditions of intense competition, clusters are more focused on business development and production growth. To do this, it is necessary to create an information system that is able to satisfy the requests of all interested users to substantiate and make management decisions, the instrument of which is financial reporting [1]. Reliable financial statements are a necessary component for the urgent provision of external and internal users with complete, truthful and impartial information about the business entity. Many scientists have paid attention to the need to control the accuracy of financial statements as a means to avoid abuse and fraud [2-4]. The object of research of many scientists was also the question of the reliability of financial information [5-7]. However, the issue of ensuring the accuracy of accounting in clusters requires further research. At present, there are no theoretical substantiations and methodological approaches to the organization of a holistic system of internal reporting, which entails the loss of the potential for its effective use in practice [5]. Therefore, the need is urgent for a perfect clarification of the economic essence of accounting in clusters and the conceptual framework for the formation of reliable reporting indicators. On this basis, it is advisable to develop proposals to prevent a material distortion of the financial results of cluster formations. Thus, the object of research is the theoretical and practical aspects of the features of the formation of management reporting and the problematic issues of preventing accounting distortions in clusters. And the aim of research is analysis of the causes of accounting distortions in clusters.

\section{Methods of research}

In the process of research methods of generalization, systematization, and system analysis were used. Using these methods, clarification of the concepts «intracorporate management reporting», «unreasonable classification of expenses» was proposed. The main problems that impede the need to implement and automate a full-fledged management accounting system that would meet all the challenges and needs of modern business are also grouped together. 


\section{Research results and discussion}

The basis for the preparation, evaluation and decision-making is accounting information, and the quality of management decisions depends on its quality. The transfer of information from the contractor to the user is carried out through reporting [5]. Therefore, it is important to timely prevent significant distortion of account information in clusters.

A distinctive feature of the system of intra-corporate management reporting is that it is formed in accordance with the organizational structure and is determined by management levels, as well as types of production processes [6]. Such factors may affect the time period for assessing the reliability of accounting information.

The collection of unnecessary cost data increases the time and resources spent on obtaining and processing such information, complicates the information system and leads to inefficient management decisions [7].

Accounting, reporting, auditing, and accordingly, the analysis of financial statements should be based on common principles and provide business partners with such information about the property and financial situation of an enterprise that was understandable, comparable, significant and reliable. The provision and analysis of transparent informativeness of financial statements, which will allow enterprises to find a promising business partner in the market, choose an effective pricing policy, is important for the Ukrainian economy and requires further research $[8,9]$.

Factors contributing to the appearance of distortion include:

- discrepancy between the value of working capital rapid growth in sales of the organization;

- dependence of the organization in a certain period from one or a small number of customers or suppliers; - change in the practice of contractual relations or in accounting policies that lead to a significant change in the amount of profit;

- atypical operations of the organization, especially during the end of the year, which significantly affect the amount of financial performance;

- availability of payments for services that are clearly not consistent with the services provided;

- features of the organizational and management structure of the organization, the presence of deficiencies in this structure;

- presence of deviations from the established rules in the conduct of accounting and organization of preparation of financial statements.

Providing inaccurate, false or incomplete information may be due to both intentional (manipulation, falsification of credentials, violations of the norms and requirements of the law), and unintentional actions (carelessness, technical error) of account workers [10].

In today's environment, an accountant is an active participant in the management process. It must have the skills of analytical work, monitor the quality of record keeping, know well the latest information systems, tax and labor laws. At the same time, the work of an accountant is in a certain sense creative. This is due, firstly, to the relatively wide freedom in the choice of methods of accounting, which requires the professional judgment of an accountant. Secondly, the need to meet a wide range of external users who require information of different cha- racteristics and composition. Thirdly, pressure from the owners of the enterprise, who seek to minimize their costs associated with the payment of taxes and other social fees [11].

Thus, in practice, there are cases when tax authorities turn to directors and accountants of enterprises with a proposal not to show losses and pay an advance payment.

Reflection of adjustments to the assessment at the balance sheet date in accounting will lead to a change in the meaning of accounting, to a distortion of its control function and to a distortion of the financial results of the enterprise [12].

Therefore, an accountant must understand that distortion, especially intentionally, of reporting, may have negative consequences.

The work of an accountant is quite responsible, and such responsibility is fixed by the legislation of Ukraine and the internal documents of the enterprise. For each incorrect step of the accountant, is directly related to his direct duties, a certain type of responsibility is envisaged, therefore, the persons who hold this position must understand and remember this [13].

To run into this, it is necessary to increase the period of use of fixed assets, improve their use, solve the problem of eliminating unused equipment (renting it, leasing, selling, etc.), calculate the cost of maintenance.

Solving the problem of increasing the efficiency of using fixed assets is one of the main tasks of enterprises, the outcome of which depends on the financial condition and competitiveness of an enterprise.

\section{Conclusions}

It is revealed that a significant distortion of financial results leads to the accounting of income and expenses on the basis of the cash method, according to which accounting for income and expenses is equal to accounting for cash flow. This negative practice is extremely common. Also in the work it is shown that insufficient information needs leads to a lack of consolidation of information, which remains unused in production. This situation occurs when there is a management accounting in separate files in different departments in accordance with the specific short-term needs of different levels of users. Therefore, in clusters it is imperative to organize effective control over the accuracy of financial statements and its use.

The research results will be useful when conducting an audit, including when planning an audit, as the accountant and the head of the company need to take into account the possible presence of distortions in the financial statements. And, on this basis, assess the risk of misstatement of financial statements and take measures to prevent such violations in the future.

\section{References}

1. Hlasov P. V. Aktualnist zastosuvannia intehrovanoi zvitnosti v klasterakh // Internauka. 2018. Issue 21. URL: https://www. inter-nauka.com/uploads/public/15449577024153.pdf

2. Wells J. T. Corporate Fraud Handbook: Prevention and Detection. Wiley, 2013. $448 \mathrm{p}$

3. Kovacich G. L. Fighting Fraud: How to Establish and Manage an Anti-Fraud Program. Cbutterworth-Heinemann, 2007. 360 p.

4. The Association of Certified Fraud Examiners // The Report to the Nation on Occupation Fraud and Abuse. Austin: ACFE, 2008. P. 19 
5. Nahirska K. Ye. Etapy formuvannia ta periodychnist podannia upravlinskoi zvitnosti // Ekonomichni nauky. Seriia: Oblik i finansy. 2010. Issue 7 (25 (2)). P. 330-338.

6. Kutsyk P. O. Suchasne traktuvannia, sklad i osoblyvosti formuvannia upravlinskoi zvitnosti pidpryiemstva // Visnyk Natsionalnoho universytetu «Lvivska politekhnika». Menedzhment ta pidpryiemnytstvo v Ukraini: etapy stanovlenni i problemy rozvytku. 2014. Issue 797. P. 248-254.

7. Fadieieva I. H., Hryniuk O. I. Suchasni aspekty upravlinskoho obliku vytrat na naftohazovydobuvnykh pidpryiemstvakh: vitchyznianyi ta zarubizhnyi dosvid // Ekonomika ta derzhava. 2015. Issue 5. P. 38-42.

8. Matrosova V. O., Sablin D. O. Analiz informatyvnosti finansovoi zvitnosti pidpryiemstv // Visnyk Natsionalnoho tekhnichnoho universytetu «KhPI»: Tekhnichnyi prohres i efektyvnist vyrobnytstva. 2011. Issue 25. P. 165-168.

9. Kurylo O. B. Sutnist, pryntsypy ta mekhanizm strukturuvannia vytrat promyslovykh pidpryiemstv // Visnyk Natsionalnoho universytetu «Lvivska politekhnika». Menedzhment ta pidpryiemnytstvo v Ukraini: etapy stanovlennia i problemy rozvytku. 2013. Issue 767. P. 39-44.
10. Bubleinyk V. A., Panna I. O. Neustoika yak vyd zabezpechennia vykonannia zoboviazannia za zakonodavstvom Ukrainy // Naukovyi visnyk Dnipropetrovskoho derzhavnoho universytetu vnutrishnikh sprav. 2010. Issue 1. P. 75-81.

11. Hnylytska L. V. Upravlinnia profesiinymy ryzykamy bukhhaltera v systemi ekonomichnoi bezpeky pidpryiemstva // Visnyk Cherkaskoho universytetu. Seriia: Ekonomichni nauky. 2016. Issue 3. P. 33-41.

12. Orlova V. K., Kafka S. M. Bukhhalterskyi oblik zakinchuietsia zvitnistiu, a MSFZ - pochynaiutsia z nei // Visnyk Natsionalnoho universytetu «Lvivska politekhnika». Menedzhment ta pidpryiemnytstvo v Ukraini: etapy stanovlennia i problemy rozvytku. 2014. Issue 794. P. 208-211.

13. Melnyk Z. Yu. Falsyfikatsiia ta vykryvlennia zvitnykh danykh vidpovidalnist prychetnykh osib // Aktualni problemy ekonomiky. 2015. Issue 7. P. 399-407.

Hlasov Pavlo, Postgraduate Student, Department of Accounting, Kyiv National Economic University named after Vadym Hetman Ukraine, e-mail: Pavel_Glasov@ukr.net, ORCID: http://orcid.org/ 0000-0003-1951-6755 